\title{
Performance model of community food business development in East Nusa Tenggara Province
}

\author{
Reyna Virginia Nona $^{1 *}$, and Maria Helena Carolinda Dua $\mathrm{Mea}^{2}$ \\ ${ }^{1}$ Economics Development Study Program, Faculty of Economics, Flores University, Indonesia \\ ${ }^{2}$ Management Study Program, Faculty of Economics, Flores University, Indonesia
}

\begin{abstract}
Community Food Business Development (PUPM) is one of the Indonesian government's programs to achieve food security. The role of farmers in PUPM are as producers, so they have an important role in realizing food security. This study aims to examine the performance model of PUPM based on the characteristics of production areas, consumption and entrepreneurship in realizing food security in East Nusa Tenggara (NTT) Province according to farmers' perceptions. The sample was 93 farmers, coming from six Gapoktans that act as Community Food Business Institutions (LUPM). The data analysis technique used is descriptive statistics and non-parametric statistics, namely Partial Least Square (PLS). The results show that the PUPM performance model based on farmers' perceptions has not been fully able to realize food security in NTT Province because it has only reached a sufficient level, the aspect of food availability has a very small contribution of $0.01 \%$, while the aspects of access and utilization and stability have been fulfilled. Therefore, to realize food security in NTT through the PUPM performance model, the aspect of food availability needs to be improved and its performance improved.
\end{abstract}

\section{Introduction}

Food is a basic need of every human being so that the fulfilment of food needs is a manifestation of the fulfilment of the human rights. Food contributes to food security and sustainability, so it is necessary to conduct a comprehensive study related to food, especially for farmers who have a dual role, namely as producers but also as consumers [1, 2].

As a basic human need, the government is obliged to establish a food policy to ensure the fulfilment of food for every society. Government policies related to food are based on the applicable Food Law, namely Law Number 18 of 2012 that is the implementations of food as basic human need must be carried out fairly, equitably, sustainably. Based on the statement in the Act, food security is one of the important things that need to be realized following the mandate of the existing Food Law.

\footnotetext{
* Corresponding author: reynamayosuku@gmail.com
} 
Availability, access, utilization, and stability are the focal concern of food security [3]. To achieve food security, the government implements the Community Food Business Development Program (PUPM). PUPM is expected to be able to fulfil every dimension of food security well for the community. The implementation of PUPM activities involves several parties, namely Association of Farmer Groups (Gapoktan) which carries out its function as a Community Food Business Institution (LUPM) and functions as a producer, Farmers Shop as a distributor, and those who play a role as rice consumers are rice buyers at Farmer Stores which are low-income people.

Farmers as producers are an important aspect in realizing food security. This is because farmers in addition to acting as producers but also as consumers. The ever changing seasons will influence the food availability [4]. Farmers also play a role in providing food for the community and raw materials for the food processing industry [5]. However, the low purchasing power of farmers is one of the factors causing the problem of farmers' inability to provide food for their households [6].

NTT Province is one of the provinces that still have food security problems [7] and food insecurity problems [8]. The PUPM activity, which is an effort by the Indonesian government to achieve food security by involving farmers, consumers and business actors, has only been able to fulfill the dimensions of food access and price stability, but the dimensions of food availability have not been fulfilled [9]. In order to overcome the food security problems, the policies carried out in each region need to be adjusted to the characteristics of each region, so that they are right on target [10].

Based on the description that has been stated, it is clear that farmers have the important role as food producers, especially staple food, namely rice. This research's objective is examine the performance model of PUPM based on the perception of rice farmers in order to realize food security in the Province of NTT. The novelty of this research is the result of a study of the PUPM performance model focused on the perceptions of rice farmers in NTT, while the same research has been carried out by [9], but this study focuses not only on the perceptions of farmers but also based on perceptions of consumers, and business actors where the analysis of the performance model is based on a diverse sample of farmers, consumers and business actors and the analysis is carried out jointly with a total of 219 respondents. The results of the study of PUPM performance model are specifically focused on studies based on farmers' perceptions because it is based on the concept that farmers have a dual role, both as food producers and food consumers, so that if the food needs of farmers are fulfilled, it is also hoped that their food production must also be can fulfill the needs of the community. Thus this research is useful for the government as policy makers, Gapoktan and business actors in the food sector, especially rice.

\section{Research method}

\subsection{Research site}

This study focused on six Gapoktans in six districts designated by the government to carry out their role as LUPM, namely the Tunmuni Gapoktan in Kupang, Roda Mandiri in North Central Timor, Eka Tua in Southwest Sumba, Sinar Usaha in West Manggarai, Rentung in Manggarai and Ine Pare in Ende. Gapoktan which acts as LUPM are located on three major islands in NTT, namely Sumba, Timor and Flores. 


\subsection{Size of sample and respondents}

The population consists of 1263 rice farmers in six Gapoktans. The number of samples was determined using the formulation of Slovin Theory (Sevila, et al 2007) so that a sample of 93 farmers was obtained and the distribution in each Gapoktan was carried out proportionally.

\subsection{Analysis method}

The indicators of the research variables are used to measure the variables which are arranged according to the research objectives. Table 1 describes the variables, indicators, parameters and measurements used in this study. 
Table 1. Research variables, indicators, parameters and measurements

\begin{tabular}{|c|c|c|c|}
\hline Variabel & Indicator & Parameter & $\begin{array}{c}\text { Measurem } \\
\text { ent }\end{array}$ \\
\hline \multirow{7}{*}{$\begin{array}{lr}\text { Characteristics } & \text { of } \\
\text { production } & \text { area } \\
(\mathrm{X} 1) & \end{array}$} & 1. Land area (X11) & Land area $\left(\mathrm{m}^{2}\right)$ & Score \\
\hline & 2. Productivity (X12) & $\begin{array}{l}\text { Comparison of total production with } \\
\text { land area (tons/ha) }\end{array}$ & Score \\
\hline & $\begin{array}{l}\text { 3. } \text { Quantity of } \\
\text { production sold (X13) }\end{array}$ & $\begin{array}{l}\text { 1) Whole production is sold, Part of the } \\
\text { production is sold, 2) Whole production } \\
\text { for own consumption }\end{array}$ & Score \\
\hline & 4. Cropping pattern & $\begin{array}{l}\text { 1) Number of plantings in a year, 2) } \\
\text { Cropping pattern }\end{array}$ & Score \\
\hline & 5. Capital & $\begin{array}{l}\text { 1) Business Scale, 2) Kinds of } \\
\text { commodities, 3) Availability of credit }\end{array}$ & Score \\
\hline & 6. Labor & $\begin{array}{l}\text { 1) Quantity, 2) Age, 3) Gender, 4) } \\
\text { Status (fixes/rented) }\end{array}$ & Score \\
\hline & 7. Management & $\begin{array}{l}\text { 1) Planning, 2) Organizing, 3) } \\
\text { Implementation, 4) Evaluation }\end{array}$ & Score \\
\hline \multirow[t]{6}{*}{$\begin{array}{l}\text { Characteristics of } \\
\text { consumption }(\mathrm{X} 2)\end{array}$} & 1. Product (X21) & $\begin{array}{l}\text { 1) Taste, 2) Color, 3) Fragrance, 4) } \\
\text { Place, 5) Texture, 6) Health benefits }\end{array}$ & Score \\
\hline & 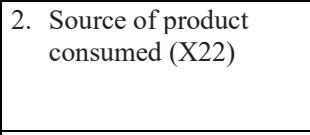 & $\begin{array}{l}\text { 1) All sourcesd from own production, 2) } \\
\text { Partly sourced from own production, } 3 \text { ) } \\
\text { All sources from buying products (other } \\
\text { rice) }\end{array}$ & Score \\
\hline & 3. Price $(\mathrm{X} 23)$ & 1) Affordable, 2) According to quality & Score \\
\hline & 4. Place (X24) & 1) Easy to get, 2) Strategic location & Score \\
\hline & 5. Private $(\mathrm{X} 25)$ & $\begin{array}{l}\text { 1) Habit, 2) Frequency, 3) Education } \\
\text { and 4) knowledge }\end{array}$ & Score \\
\hline & 6. Motivation (X26). & $\begin{array}{l}\text { 1) Fulfill basic needs, 2) Household } \\
\text { food reserves, 3) Get profit }\end{array}$ & Score \\
\hline \multirow[t]{6}{*}{$\begin{array}{l}\text { Characteristics of } \\
\text { entrepreneurship } \\
\text { (X3) }\end{array}$} & 1. Confident (X31) & $\begin{array}{l}\text { 1) Persistence, 2) Independence, 3) } \\
\text { Good personality, 4) Think } \\
\text { optimistically }\end{array}$ & Score \\
\hline & $\begin{array}{l}\text { 2. Task and result } \\
\text { oriented (X32) }\end{array}$ & $\begin{array}{l}\text { 1) The need for achievement, 2) Profit } \\
\text { oriented, 3) Diligent and steadfast, 4) } \\
\text { Determination hard work and } \\
\text { motivation, 5) Energetic, 6) Full of } \\
\text { initiative }\end{array}$ & Score \\
\hline & $\begin{array}{l}\text { 3. Dare to take risk } \\
\text { (X33) }\end{array}$ & $\begin{array}{l}\text { 1) Able to speculate, 2) Like to take } \\
\text { risk, 3) Likes challenges }\end{array}$ & Score \\
\hline & 4. Leadership (X34) & $\begin{array}{l}\text { 1) Able to take initiative, 2) Able to } \\
\text { work together, 3) Easy to get along, 4) } \\
\text { Respond to suggestions and criticism, 5) } \\
\text { Great desire to achive results, 6) Able to } \\
\text { influence others }\end{array}$ & Score \\
\hline & 5. Originality (X35) & $\begin{array}{l}\text { 1) Innovative, 2) Creative, 3) Flexible, } \\
\text { 4) Many sources, 5) Versatile, 6) } \\
\text { Knowing a lot }\end{array}$ & Score \\
\hline & 6. Future oriented (X36) & $\begin{array}{l}\text { 1) Have a vision, Not satisfied quickly, } \\
\text { 2) Develop and evaluate yourself }\end{array}$ & Score \\
\hline \multirow[t]{3}{*}{$\begin{array}{l}\text { PUPM Performance } \\
\text { (Y) }\end{array}$} & $\begin{array}{l}\text { 1. Increasing the success } \\
\text { of farming (Y1) }\end{array}$ & $\begin{array}{l}\text { 1) Production increase, 2) Increase } \\
\text { income }\end{array}$ & Score \\
\hline & \begin{tabular}{|l} 
2. Ease of consumers \\
accessing rice at an \\
affordable price (Y2) \\
\end{tabular} & Basic needs (rice) are met & Score \\
\hline & $\begin{array}{l}\text { 3. Increasing Gapoktan } \\
\text { and TTI business } \\
\text { profits (Y3) }\end{array}$ & $\begin{array}{l}\text { 1) Increasing business scale, 2) Gaining } \\
\text { consumer trust }\end{array}$ & Score \\
\hline
\end{tabular}


The data is analyzed technique used in this study is descriptive statistical analysis and non-parametric statistics, namely data analysis techniques that use a variance-based approach or known as Partial Least Square (PLS). PLS is a variant-based structural equation analysis method that may test the measurement model as well as the model itself at the same time. This study uses PLS analysis because it can predict the model for theory development.

The PUPM performance model based on the perception of rice farmers using PLS is shown in Figure 1.

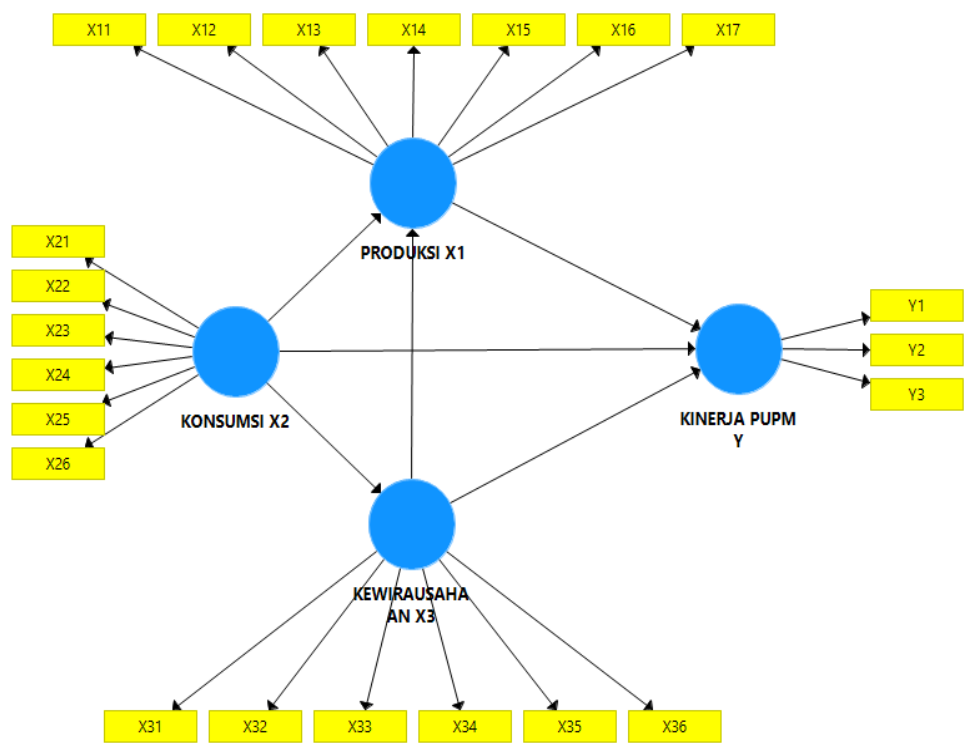

Fig. 1. Empirical Model of PUPM Performance Based on the Perception of Rice Farmers

\section{Result and discussion}

\subsection{Characteristics of rice farmers in East Nusa Tenggara}

Characteristics of rice farmers in East Nusa Tenggara (NTT) can be presented in Table 2. 
Table 2. Characteristics of rice farmers in NTT

\begin{tabular}{|l|c|c|c|}
\hline \multicolumn{1}{|c|}{ Component } & Characteristics & Number of People & Percentage (\%) \\
\hline Gender & Male & 84 & 90,32 \\
& Female & 9 & 9,68 \\
\hline Land Area & $<0,5$ & 19 & 20 \\
& $0,5-1$ & 60 & 64 \\
& $>1$ & 15 & 16 \\
\hline Cropping Pattern & Paddy-paddy & 75 & 80,65 \\
& Paddy-palawija-paddy & 18 & 19,35 \\
\hline Planting Time & One time & 5 & 5,38 \\
& twice & 88 & 94,62 \\
\hline Age & $17-25$ & 6 & 6,45 \\
& $26-45$ & 60 & 64,52 \\
& $46-55$ & 24 & 25,81 \\
& $>56$ & 3 & 3,23 \\
\hline Education & Primary School & 36 & 38,71 \\
& Junior High School & 29 & 31,11 \\
& Senior High School & 28 & 30,18 \\
\hline The number of & $0-2$ & 35 & 37,63 \\
dependents & $3-5$ & 49 & 52,69 \\
& $6-7$ & 9 & 9,68 \\
\hline Land ownership & Own Land & 81 & 87,10 \\
status & Cultivator & 12 & 12,90 \\
\hline
\end{tabular}

Source: Analysis results, 2018

Based on the data in Table 2, it can be seen that rice farmers in NTT need to optimize land use properly to provide for the food needs of the farmers' families. The number of dependents of the farmer's family is one of the factors that influence the food needs of the farmer's household, although the productive age of the rice farmer and land ownership can be factors that support the success of rice farming activities.

\subsection{Validity and reliability test}

A valid instrument is the right instrument to measure something which is done by correlating the score of the instrument item with the total score of all question items. If in the validity test the coefficient value is more than 0.3 , then the question or statement in the instrument is declared valid. While reliability is useful to see consistency. A good reliability coefficient value is if it gives Cronbach's alpha value above 0.6.

The validity test result indicated that, of the research instrument on the respondents of rice farmers, it is known that the correlation coefficient value for each question indicator is a strong construct because it has a correlation coefficient appropriate value of $>0,3$. Thus the measuring instrument used in this study has met validity as an instrument.

The results of the reliability test of the research instrument on the respondents of rice farmers showed that the value Cronbach's Alpha $>0.6$ so that the variables of Characteristics of Production Areas (X1), Consumption (X2), Entrepreneurship (X3), and PUPM Performance (Y) were acceptable with a reliability value level of 0.650. $-0,936$.

\subsection{Evaluation of the measurement model (outer model)}

Evaluation of the measurement model (outer model) was carried out on a model based on the perceptions of rice farmers. This study has four latent variables, namely the characteristics of the production area (X1), consumption characteristics (X2), 
entrepreneurial characteristics (X3), and PUPM performance (Y). Because the measurement model used reflective indicators, the convergent and discriminant validity of the indicators, as well as the composite reliability because the measurement model used uses reflective indicators.

Based on Figure 1, it appears that the indicator of the number of products sold (X13) outer loading 0.652 and the source of the product consumed (X22) outer loading 0.697 are invalid indicators, because outer loading $<0.700[11,12]$. The indicator is removed from the model and the outer model is tested again and the results are shown in Figure 2.

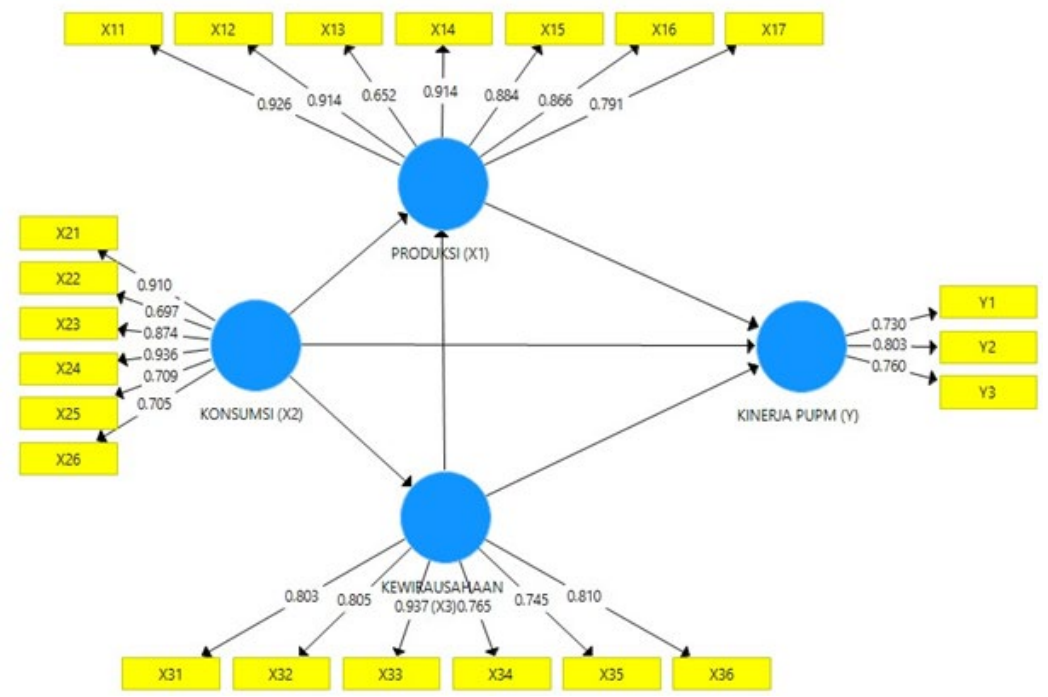

Fig. 2 Testing the router model based on the perceptions of rice farmers

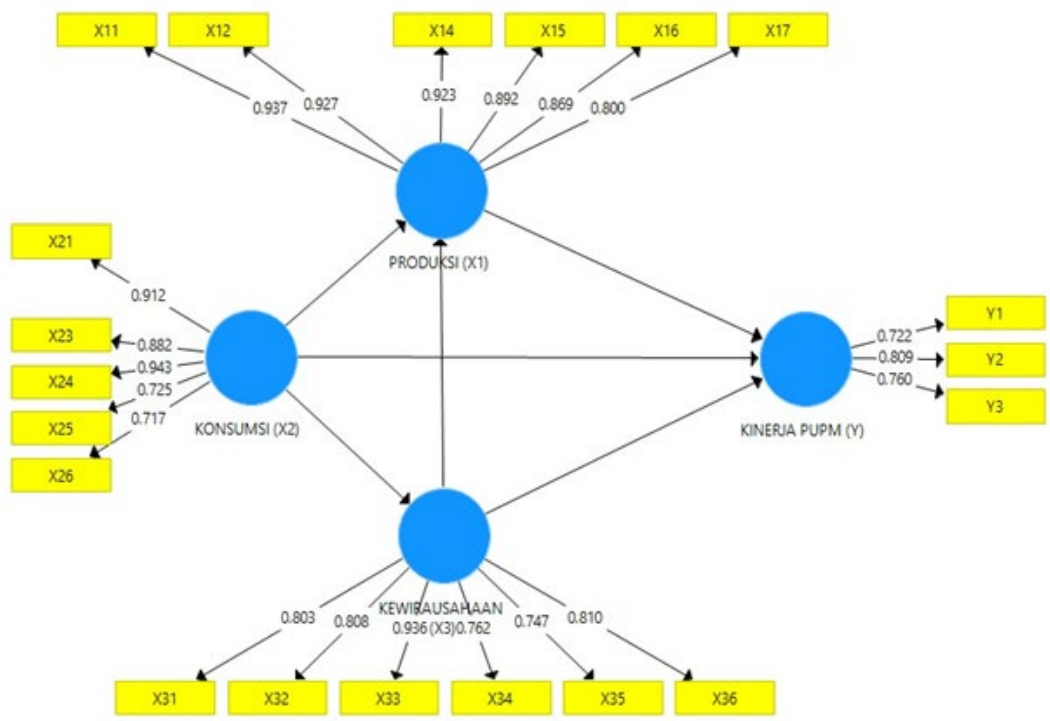

Fig. 3 Testing the router model based on the perceptions of rice farmers after being corrected

Based on the information in Figure 2, it is known that the results of the calculate of the perceptions of rice farmers on production characteristics, all indicators used are valid indicators because the outer loading is $>0.700$. Likewise, the indicators used to measure the 
perceptions of rice farmers on the characteristics of consumption, entrepreneurship, and performance of $P U P M$.

Evaluation of the discriminant validity of the measurement model with the reflection indicator in this study used the value of cross loading, average variance extracted (AVE), and the square root of average variance extracted (roots A V E). The discriminant validity of the measurement model is assessed based on the measurement of cross-loading with the construct. The cross-loading value is said to be valid if the construct correlation with the measurement subject for each indicator is greater than the other constructs and the value is $>$ $0.700[11,12]$. Latent constructs can predict indicators better than other constructs. AVE and the root of AVE are indicators that are used to explain that the indicators used can explain the variables that are formed than other indicators. If the AVE root value of each latent variable is greater than the AVE value of the latent variable, then the instrument variable is also said to be a valid discriminant. Discriminant validity testing can be explained as follows:

1) Cross loading

The results of the calculation of cross-loading for the constructs of the characteristics of production, consumption, and entrepreneurship areas show that the cross-loading value on all indicators is $>0.700$ so that all indicators used are said to be discriminant valid.

2) Average variance extracted (AVE) and an $r A V E$.

The results of the calculation of the AVE and root values on the variable characteristics of the production area, consumption, entrepreneurship, and performance of the PUPM show that they are above the tolerance limit value of 0.500 so that the instrument for each variable is said to be valid discriminant $[11,12]$.

Table 3 shows the AVE Value and AVE Root of the research variables based on the perceptions of rice farmers.

Table 3. The value of AVE and the AVE root of the research variables was based on the perceptions of rice farmers

\begin{tabular}{|l|c|c|c|}
\hline \multicolumn{1}{|c|}{ Variable } & AVE & AVE Root & Information \\
\hline Characteristics of Production Areas (X1) & 0,797 & 0,893 & Valid \\
\hline Consumption Characteristics (X2) & 0,708 & 0,841 & Valid \\
\hline Entrepreneurial Characteristics (X3) & 0,661 & 0,813 & Valid \\
\hline PUPM Performance (Y) & 0,584 & 0,764 & Valid \\
\hline
\end{tabular}

Source: Analysis results, 2018

The reliability test of a construct with reflective indicators is carried out using composite reliability and Cronbach's Alpha. The value of composite reliability and Cronbach's Alpha is said to be good if the value is $>0.60$ and shows that discriminant validity has been achieved $[11,12]$. The results of testing the composite reliability and Cronbach's Alpha measurement model of this study show that all the variables tested are reliable so that the latent variables used have good composite reliability and have highreliability values. All instruments of rice farmers' perceptions of the characteristics of the production area, consumption, entrepreneurship, and performance of PUPM used in this study have met the criteria or are feasible to be used in the measurement of all latent variables and can then be used to evaluate inner models or evaluation of structural models. Table 4 shows the value of composite reliability and Cronbach's alpha research variables based on the perceptions of rice farmers. 
Table 4. The value of composite reliability and Cronbach's alpha research variables was based on the perceptions of rice farmers

\begin{tabular}{|c|c|c|c|}
\hline Variable & $\begin{array}{c}\text { Composite } \\
\text { reliability }\end{array}$ & $\begin{array}{c}\text { Cronbach's } \\
\text { Alpha }\end{array}$ & Information \\
\hline Characteristics of Production Areas (X1) & 0,959 & 0,948 & Reliable \\
\hline Consumption Characteristics (X2) & 0,923 & 0,893 & Reliable \\
\hline Entrepreneurial Characteristics (X3) & 0,921 & 0,900 & Reliable \\
\hline PUPM Performance (Y) & 0,808 & 0,650 & Reliable \\
\hline
\end{tabular}

Source: Analysis results, 2018

\subsection{Evaluation of the structural model (inner model)}

The evaluation of the structural model (inner model) aims to see the relationship between the latent construct (causal path) and the estimated result of the path parameter coefficient and its significance level to test the predetermined hypothesis. The structural model of this study was analysed using bootstrapping techniques and evaluated by paying attention to the $\mathrm{R}$-square value $\left(\mathrm{R}^{2}\right)$ obtained from the goodness of fit model test and the Q-Square $\left(\mathrm{Q}^{2}\right)$ value from the predictive relevance model test. The value of $\mathrm{Q}^{2}$ is based on the coefficient of determination $\left(\mathrm{R}^{2}\right)$ of all endogenous variables which aims to measure how well the observed value is generated by the model. The quantity of $\mathrm{Q}^{2}$ has a value with a range of 0 $<\mathrm{Q}^{2}<1$, the closer to the value of 1 , the better the model $[11,12]$.

The results of the analysis of the coefficient of determination $\left(\mathrm{R}^{2}\right)$ of the structural model based on the perceptions of rice farmers are depicted in Table 5. The variable characteristics of the production area can be explained by the consumption and entrepreneurial characteristics variables of 0.235 or $23.5 \%$, while the rest is explained by other factors not examined. The entrepreneurial characteristics variable can be explained by the consumption characteristic variable of 0.173 or $17.3 \%$, while the rest is explained by other factors not examined. PUPM performance variables can be explained by the characteristics of the production area, consumption, and entrepreneurship variables of 0.514 or $51.4 \%$, while the rest is explained by other factors not examined. Based on the results of the analysis, the $\mathrm{R}^{2}$ value is 0.514 and according to Ghozali (2008), this value is classified as a moderate or sufficient model, thus the characteristics of the production, consumption and entrepreneurship area variables are moderately able to explain the performance of PUPM.

Table 5. The coefficient of determination is based on the perceptions of rice farmers

\begin{tabular}{|l|l|l|}
\hline \multicolumn{1}{|c|}{ Influence } & \multicolumn{1}{|c|}{ Toward } & R Square \\
\hline $\begin{array}{l}\text { Consumption Characteristics (X2) } \\
\text { Entrepreneurship Characteristics (X3) }\end{array}$ & $\begin{array}{l}\text { Characteristics of Production Area } \\
\text { (X1) }\end{array}$ & 0,235 \\
\hline Consumption Characteristics (X2) & Entrepreneurship Characteristics (X3) & 0,173 \\
\hline $\begin{array}{l}\text { Characteristics of Production Area (X1) } \\
\begin{array}{l}\text { Consumption Characteristics (X2) } \\
\text { Entrepreneurship Characteristics (X3) }\end{array}\end{array}$ & PUPM Performance (Y) & 0,514 \\
\hline
\end{tabular}

Source: Analysis results, 2018

Based on the value of the coefficient of determination $\left(\mathrm{R}^{2}\right)$ of the endogenous variable $P U P M$ Performance (Y), the $\mathrm{Q}^{2}$ value can be calculated as follows:

$$
\begin{aligned}
Q^{2} & =1-\left(1-R^{2}\right) \\
& =1-(1-0.514) \\
& =0.514
\end{aligned}
$$

After obtaining a $\mathrm{Q}^{2}$ value of 0.514 , the structural model based on the perceptions of rice farmers shows acceptable suitability and has a strong predictive relevance, because the 
value is $>0.35[11,12]$. This means that the latent variables in the structural model can predict the model well and can be used to test the hypothesis of this study.

Based on the results of the structural model analysis, hypothesis testing can be carried out by looking at the estimated value of the path coefficient and the significant critical point value at the $95 \%$ confidence level or the significant probability value ( $p$-value) $<5 \%(0.05)$ and with the t-statistic value. $>\mathrm{t}$-table which is 1.662 , then the proposed hypothesis can be accepted.

The results of the path coefficient and hypothesis testing can be seen in Table 6 and Figure 3. Based on the results of the analysis, it can be seen that the three exogenous variables, namely the characteristics of the production area (X1), consumption (X2), and entrepreneurship (X3) have a positive path coefficient value and have a t-value. - statistics $>$ 1.662 and p-value $<0.05$ for endogenous variables, namely PUPM performance. These three variables have a direct and significant effect on the PUPM performance variable (Y).

Table 6. The path coefficient, $t$-statistic, and $p$-value of the structural model are based on the perceptions of rice farmers

\begin{tabular}{|l|l|c|c|c|c|}
\hline \multicolumn{1}{|c|}{ Influence } & Toward & $\begin{array}{c}\text { Path } \\
\text { Coefficient }\end{array}$ & $\begin{array}{c}\text { t stat } \\
(\mathbf{1 , 6 6 2})\end{array}$ & $\begin{array}{c}\text { p value } \\
(\mathbf{0 , 0 5})\end{array}$ & Information \\
\hline $\begin{array}{l}\text { Characteristics of } \\
\text { Production Area (X1) }\end{array}$ & PUPM Performance (Y) & 0,507 & 6,078 & 0,000 & $\mathrm{Sig}$ \\
\hline $\begin{array}{l}\text { Consumption } \\
\text { Characteristics (X2) }\end{array}$ & PUPM Performance (Y) & 0,173 & 1,943 & 0,000 & $\mathrm{Sig}$ \\
\hline $\begin{array}{l}\text { Entrepreneurship } \\
\text { Characteristics (X3) }\end{array}$ & PUPM Performance (Y) & 0,259 & 3,429 & 0,001 & $\mathrm{Sig}$ \\
\hline $\begin{array}{l}\text { Consumption } \\
\text { Characteristics (X2) }\end{array}$ & $\begin{array}{l}\text { Characteristics of } \\
\text { Production Area (X1) }\end{array}$ & 0,508 & 6,916 & 0,000 & $\mathrm{Sig}$ \\
\hline $\begin{array}{l}\text { Consumption } \\
\text { Characteristics (X2) }\end{array}$ & $\begin{array}{l}\text { Entrepreneurship } \\
\text { Characteristics (X3) }\end{array}$ & 0,416 & 5,275 & 0,000 & $\mathrm{Sig}$ \\
\hline $\begin{array}{l}\text { Entrepreneurship } \\
\text { Characteristics (X3) }\end{array}$ & $\begin{array}{l}\text { Characteristics of } \\
\text { Production Area (X1) }\end{array}$ & $-0,066$ & 0,793 & 0,562 & Not Sig \\
\hline
\end{tabular}

Source: Analysis results, 2018

The analysis results also show the relationship between the three exogenous variables, it can be seen that the consumption characteristic variable (X2) has a direct and significant effect on the production area characteristic variable (X1) where the t-statistic value = $6.916>1,662$ and $p$-value $=0.000<005$. The consumption characteristics variable (X2) has a direct and significant effect on the entrepreneurial characteristics variable (X3), where the $\mathrm{t}$-statistic value $=5,276>1,662$ and $\mathrm{p}$-value $=0,000<0.05$. The entrepreneurial characteristics variable (X3) has no direct and insignificant effect on the production area characteristic variable (X1) because it has a negative path coefficient value and has a tstatistic value $=0.793<1.662$ and $p$-value $=0.562>0.05$.

The results of the path coefficient analysis, t-statistical critical point value, and p-value also aim to answer the proposed hypothesis. The results of the structural model analysis based on the perceptions of rice farmers show empirically strong evidence to accept the proposed hypothesis, namely the characteristics of the production area, consumption and entrepreneurship simultaneously affect the performance of PUPM in NTT Province. 


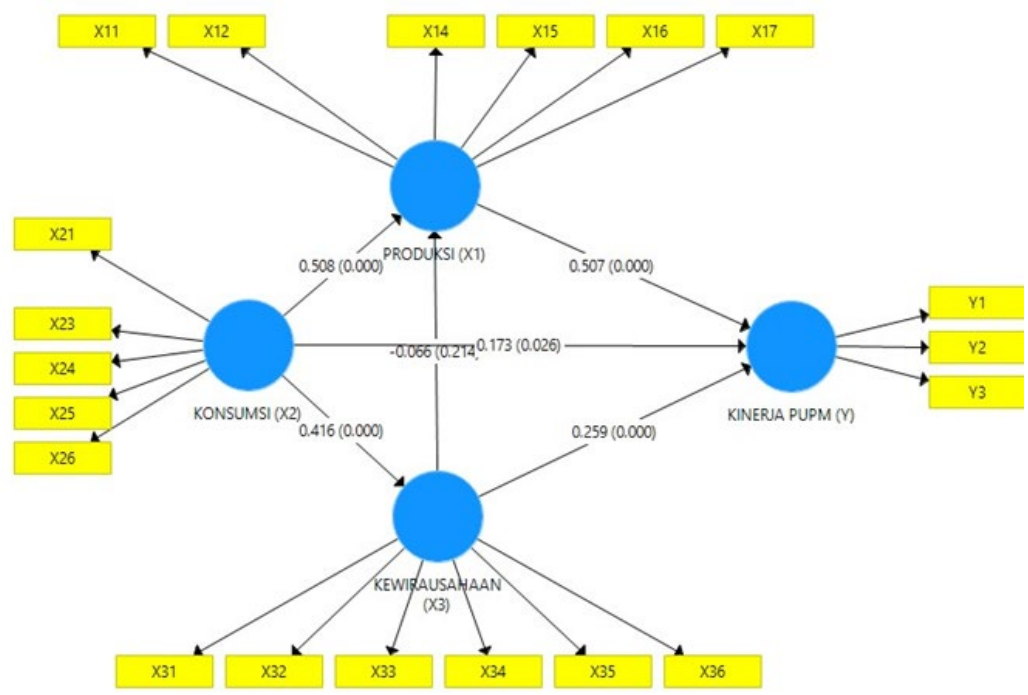

Fig. 4 The path coefficient and p-value of the structural model are based on perceptions of rice farmers

PUPM's good performance can realize community food security. Based on the data in Table 7, it is known that the role of PUPM is still very small, namely, only $0.01 \%$ of the rice consumption needs in NTT in 2017 in meeting the aspect of food availability. Based on the aspects of access and benefits of food, $99.18 \%$ of rice from PUPM can be accessed and utilized by low-income people. Based on the stability aspect, it is known that there is a small gap between the market price and the price at TTI, which is IDR 1,100. Thus, the existing PUPM performance model has been able to realize regional food security in NTT from the aspects of access, utilization, and price stability of the food, while the aspect of availability plays a very small role.

Table 7. NTT Food Security Data

\begin{tabular}{|l|c|}
\hline \multicolumn{1}{|c|}{ Availability aspect } & Value \\
\hline Rice production & 1.090 .821 -ton GBK \\
\hline Convert to the amount of rice & $65 \% \times 1.090 .821$ ton=706.683,65 ton \\
\hline Rice Consumption Average & $113 \mathrm{~kg} / \mathrm{capita} /$ year \\
\hline Population & 5.203 .500 people \\
\hline The need for rice consumption & $\begin{array}{l}113 \times 5.203 .500=587.995 .500 \mathrm{~kg} / \mathrm{year} \text { or } \\
587.995,50 \mathrm{ton} .\end{array}$ \\
\hline The amount of rice distributed by $P U P M$ & $57.754: 587.995 .500=0,01 \%$ \\
\hline \multicolumn{1}{|c|}{ Access and Utilization Aspects } & $57.754 \mathrm{~kg}$ \\
\hline The amount purchased by Gapoktan from farmers & $57.282 \mathrm{~kg}(99,18 \%)$ \\
\hline The amount that goes to TTI & $472 \mathrm{~kg}(0,82 \%)$ \\
\hline Amount sold directly to Public & $\mathrm{Rp} 9.000 / \mathrm{kg}$ \\
\hline \multicolumn{1}{|c|}{ Stability Aspects } & $\mathrm{Rp} 9.500-\mathrm{Rp} 10.000$ \\
\hline The price of rice at harvest at the farm level & $\mathrm{Rp} 500-\mathrm{Rp} 1.000$ \\
\hline Post-harvest rice prices & $\mathrm{Rp} 7.900$ \\
\hline The difference in price at harvest and post-harvest & $\mathrm{Rp} 1.100$ \\
\hline The price of rice at TTI & $\begin{array}{l}\text { The difference between the market price and } \\
\text { the price at TTI }\end{array}$ \\
\hline
\end{tabular}

Source: Secondary data processed, 2018. 


\section{Conclusion}

Based on the results of the analysis and discussion, it can be concluded that the PUPM performance model based on the perceptions of producer has not been fully able to realize food security in Province of NTT because it has only reached a sufficient level $\left(\mathrm{R}^{2}=\right.$ 0.514). Aspects of food availability has a very small contribution, namely $0.01 \%$. Aspects of access and utilization, it is found out that $99.18 \%$ of rice from Gapoktan has been distributed to TTI to meet consumer needs, thus fulfilling aspects of access and utilization. Aspects of stability, it appears that the price difference in the market with the price in TTI is not large so that it fulfills the price stability aspect. Therefore, to realize food security in NTT Province through the PUPM performance model, the aspect of food availability needs to be improved and its performance is enhanced

\section{References}

1. Prihatin, S.D., S.S. Hariadi, and M. Mudiyono, Civis. 11, 2 (2012)

2. Okki Wijaya, W.W., Riskhi Lathifah, Nur Rahmawati, Cahyo Wisnu Rubiyanto, Journal of Agribusiness and Rural Development Research. 6, 2 p. 168-180 (2020).

3. Methot, J. and E.M. Bannet, PLoS ONE. 13, 5 (2018).

4. Januar, M. and S. Sumardjo, Jurnal Penyuluhan. 6. 2 (2010).

5. Sadono, D., Junal Penyuluhan. 4, 1 (2018).

6. Deffrinica, Vuspirasari, B. Kikky, Hapsari, and V. Rini, Business, Economics and Entrepreneurship. 2, 1 (2020).

7. Permatasari, D.L. and V. Ratnasari, Jurnal Sains dan SeniI ITS. 5, 2 p. 2337-3520 (2016).

8. Purwantini, B.T., Forum Penelitian Agroekonomi. 32, 1 p. 1-17 (2014).

9. Nona, R.V., I.G.A.A. Ambarawati, D.P. Darmawan, and I.W. Budiasa, International Journal of Agriculture System. 6, 2 p. 146-155 (2018).

10. Nona, R.V. and I.A.K. Juniasih, Jurnal Pengkajian dan Pengembangan Teknologi Pertanian. 23, 2 p. 151-162 (2020).

11. Gozali, I., Structural Equations Modeling. Metode Alternatif dengan Partial Least Square. (Semarang: BP Universitas Diponegoro, 2008).

12. Hair, J.F., G.T.M. Hult, C.M. Ringle, and M. Sarstedt, A Primer on Paartial Least Squares Structural Equation Modeling (PLS-SEM). (United States of America: SAGE, 2014). 